\title{
Sustainable Design of HVAC in University Campus
}

\author{
Zhao yuqing $^{1 \mathrm{a}}$,Liu Qingqing ${ }^{1}$ \\ ${ }^{1}$ North China University of Technology, Shi jing Shan, Beijing, China, 100144 \\ 1aemail:zyqbj@126.com
}

Keywords: Sustainable design; University campus; energy saving; HVAC

Abstract. Universities consume a large amount of energy resources during personnel training. Construction of conservation-oriented campus is one of the important tasks faced in the development of universities. Taking NCUT (North China University of Technology) for example, this paper proposes sustainable design of HVAC (Heating Ventilation Air Conditioning). Several feasible energy saving techniques including the water source heat pump technology, solar energy technology and energy recycling technology are proposed in the present study, so as to provide reference for universities in building energy saving campus.

\section{Introduction}

In China, higher education has undergone tremendous expansion in architectural scale in the recent past. The campus energy consumption accounts for $8 \%$ of the total social energy consumption and the energy consumption value of each college student is 4 times that of the general public ${ }^{[1] .}$ To improve energy conservation, several schools partnership have been set up in China, such as NUECA(National Energy Conservation Alliance),CGUN(China Green University network) and UAIEE(University Alliance for Industrial Energy Efficiency) ${ }^{[2]}$. The concept of sustainable development and the low carbon activities in campus caused a trend in the world countries. At present, there are nearly 4000universities had applied and received the certification of LEED ${ }^{[3]}$.

Hence, study on the application of energy saving in building in colleges and universities are of great significance to promote the scientific development and the implementation of national energy conservation and emission reduction plan. The campus buildings such as libraries, gymnasiums, teaching buildings, student apartments, student bathhouses and hotels usually consume large amount of energy to fulfill the important task of education, science research and social service. As heating and cooling energy consumption accounts for about a third of the energy consumption of buildings, energy-saving HVAC design plays an important role in achieving sustainable design. Several feasible energy saving techniques including the water source heat pump technology, solar energy technology and energy recycling technology are proposed in the design of HVAC in the present study.

\section{Reclaimed water source heat pump technology}

Most of the sewage of colleges and universities will be processed into reclaimed water and then be reused.The temperature of reclaimed water is relatively stable throughout the year $\left(12-22^{\circ} \mathrm{C}\right.$ ), in which contains available energy that could be recover by heat pump.

\section{Project overview}

The project is about the reclaimed water source heat pump to replace the traditional gas boiler heating water renovation project in North China University of Technology, in which there are 15000 
students.Domestic hot water is mainly used in the students' bathroom and school hotel. There are 250 shower heads in the students' bathroom. The school hotel arranged 132 standard rooms, hot water supply for 24 hours a day. Before renovation the heat source is a $2.1 \mathrm{MW}$ gas-fired boiler and equipped with a 70t hot water storage tank. Average daily water consumption of hot water is $160 \mathrm{~m}^{3}$.

The reclaimed water treatment station produces reclaimed water 900t per day, under normal circumstances, all the sewage of school will be processed into reclaimed water and then be reused. The average temperature of reclaimed water is $25^{\circ} \mathrm{C}$. Based on the existing conditions of the bathroom and the reclaimed water station, a reclaimed water source heat pump is designed to provide hot water for the bathroom and the school hotel to replace the existing gas-fired boiler. After the heat of reclaimed water is extracted by the heat pump, the temperature is reduced to $3-5^{\circ} \mathrm{C}$, which is used for flushing and watering the green space, so as to realize zero discharge of waste water energy.

\section{System process and design points}

The temperature of the hot water for bathroom is $40{ }^{\circ} \mathrm{C}$, and $55{ }^{\circ} \mathrm{C}$ for school hotel respectively. Water system principle was shown in Figure 1.The gas boiler is used as backup when the heat pump is in maintenance. Design points:

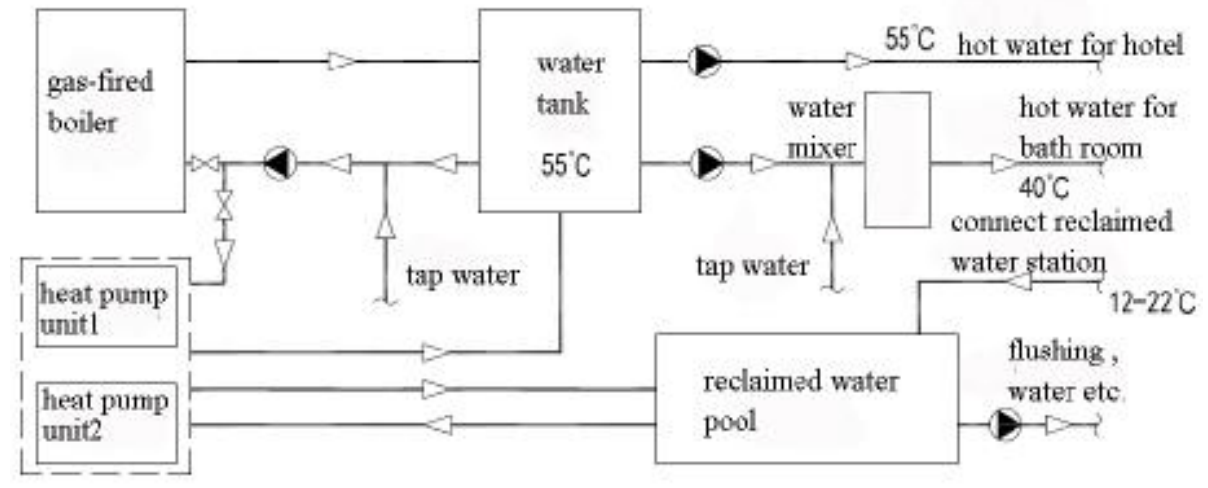

Fig.1 Schematic diagram of water system

\section{1) Heat balance between the required heat and the amount of heat in reclaimed water}

Water flow and suitable water temperature must meet the requirements of water source heat pump operation. The daily production of reclaimed water is $900 \mathrm{~m}^{3}$ and the average hot water consumption is $160 \mathrm{~m}^{3}$. Through the heat balance calculation, the available heat of reclaimed water in winter is $42 \mathrm{GJ}$, and the heat requirement for hot water is about $41 \mathrm{GJ}$, indicating that the heat contained in the reclaimed water can theoretically satisfied the heat demand.

2) Matching of sewage system, reclaimed water system and heat pump system

The combined operating of the sewage system, the intermediate water system and the heat pump system requires well matching between the three systems. In this project, the sewage storage tank capacity is $650 \mathrm{~m}^{3}$, reclaimed water is stored in a water tank $\left(600 \mathrm{~m}^{3}\right)$, the heat capacity of the heat pump is $1000 \mathrm{~kW}$, the volume of the hot water storage tank is $110 \mathrm{~m}^{3}$. As the volume of the tank is related to the evaporation temperature of the heat pump, it is necessary to analyze the tank volume of the reclaimed water.

The relationship between the reclaimed water temperature and the reclaimed water tank is shown in figure 2. It can be seen that with the increase of the tank volume, the fluctuation range of the water 
temperature is reduced, When the volume of the pool is $600 \mathrm{~m}^{3}$, the water temperature is between $12-22^{\circ} \mathrm{C}$, in which the heat pump operation with higher performance coefficient.

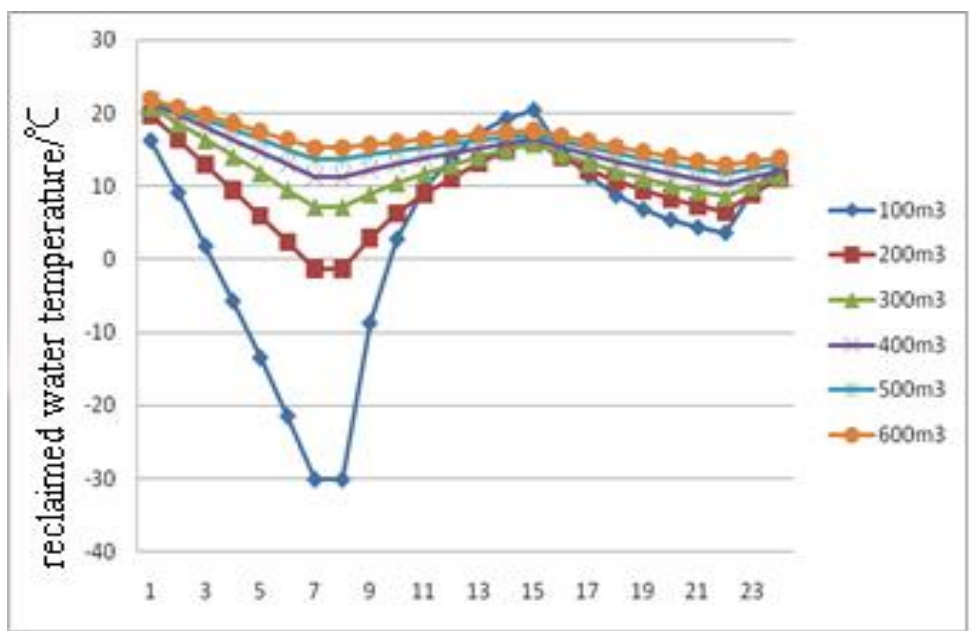

Fig. 2 The relationship between the reclaimed water temperature and the tank volume

\section{3) Control system}

This project uses the PLC control technology and the German SIMENS controller.

\subsection{Analysis of economy, energy saving and environmental protection}

\section{(1) Analysis of economy}

The annual cost includes annual fixed cost and annual operating cost, and the annual fixed cost refers to the annual consumption of the total investment of each equipment in the system. The calculation is shown in formula $(1)^{[4]}$.

$$
F_{A}=\sum_{j=1}^{N} i g_{(1+i)^{m}-1}^{m} g K_{j}+C
$$

Where $F_{A}$ is the annual calculation cost calculated by the dynamic method, yuan/a; $K$ is system equipment (number j) investment, yuan; $m$ is system equipment service life, $m=15 \mathrm{a} ; C$ is annual operating cost, yuan/a; $i$ is the standard rate of return within the department, $\mathrm{i}=8 \%$.

Table1 Comparison of the economy of two systems

\begin{tabular}{lclll}
\hline & $\begin{array}{c}\text { Initial } \\
\text { investment } \\
\left(10^{4} \text { yuan }\right)\end{array}$ & $\begin{array}{l}\text { Annual } \\
\text { fixed cost } \\
\left(10^{4} \text { yuan }\right)\end{array}$ & $\begin{array}{l}\text { annual operation } \\
\text { cost }\left(10^{4} \text { yuan }\right)\end{array}$ & $\begin{array}{l}\text { annual cost } \\
\left(10^{4} \text { yuan }\right)\end{array}$ \\
\hline $\begin{array}{l}\text { Reclaimed water source } \\
\text { heat pump system }\end{array}$ & 81.25 & 9.5 & 37.0 & 46.5 \\
Gas - fired boiler & 62.5 & 7.3 & 45.0 & 52.3 \\
\hline
\end{tabular}


As can be seen from table 1, compared with gas-boiler heating system, the reclaimed water source heat pump system is $23 \%$ higher than the former on initial investment and $18 \%$ lower on annual operating cost. Payback period of investment is 3 years, which proves that it is feasible in economy to produce domestic hot water by using reclaimed water source heat pump technology.

(2) Analysis of energy saving and environmental protection

When reclaimed water source heat pump units is used to replace gas-boiler, the amount of gas saved per day can be caculated by formula $(2)^{[5]}$ :

$$
M_{1}=M_{b}-M_{H}=\frac{Q_{R}}{q_{b}}\left(\frac{1}{\eta_{b}}-\frac{1}{\eta_{e} \times C O P}\right)
$$

Where $M_{l}$ is the amount of gas save per day, $\mathrm{m}^{3} ; M_{b}$ is average daily gas consumption of gas-fired boiler, $\mathrm{m}^{3} ; M_{H}$ is the amount of gas equivalent to the electricity consumed by the reclaimed water source heat pump, $\mathrm{m}^{3} ; Q_{R}$ is the daily heat supply of the heat pump unit, taking $Q_{R}=4.14 \times 10^{7} \mathrm{~kJ} ; q_{b}$ is the calorific value of natural gas; $\eta_{b}$ is the thermal efficiency of gas-fired boiler, taking $90 \%$; $\eta_{e}$ is power input efficiency, take $30 \%$.

According to the formula (2), the reclaimed water source heat pump system can save $515.4 \mathrm{~m}^{3}$ natural gas every day, $1 \mathrm{~m}^{3}$ natural gas is equivalent to $1.527 \mathrm{~kg}$ standard coal ${ }^{[6]}$, then the gas saved per day is equivalent to $787 \mathrm{~kg}$ standard coal. Taking 300 days as annul operation time, the annual saving of natural gas is $154500 \mathrm{~m}^{3}$, which means saving $237 \mathrm{t}$ standard coal. Emission reduction of harmful gas is shown in table 2.

Table2 Annul emission reduction of pollutant

\begin{tabular}{lrrrr}
\hline pollutant & $\mathrm{CO}_{2}$ & $\mathrm{NO}_{\mathrm{x}}$ & $\mathrm{SO}_{2}$ & Dust \\
\hline $\begin{array}{l}\text { emission } \\
\text { reduction }\end{array}$ & 649.29 & 0.94 & 7.83 & 4.72 \\
\hline
\end{tabular}

\section{Solar thermal and photovoltaic technologies}

Beijing is rich in solar energy resources, the annual solar radiation is more than $5000-6000 \mathrm{MJ} / \mathrm{m}^{2}$, providing excellent natural conditions for the use of solar energy ${ }^{[7]}$.

\section{Solar photovoltaic technology}

\section{(1) Photovoltaic building integration technology program}

The roof of the Second Building is equipped with solar panels, the installation direction and position of solar panels should be based on the indoor lighting and shading requirements, as shown in figure3.

Solar panels were installed on the roof steel frame and the horizontal southward sunshade steel frame on the low zone of the Forth Building. A total of 2000 panels were installed on two buildings, with an area of $3260 \mathrm{~m}^{2}$,as shown in figure 4 .

(2) Effect of energy saving and emission reduction

The solar energy of the Second Building and the Forth Building is converted into electric energy for illumination of these two buildings and other adjacent buildings. The average monthly power generation is shown in figure 5 . The average total generating capacity is $470 \mathrm{kWP}$, annual generating capacity is $566000 \mathrm{kw} \cdot \mathrm{h}$, equivalent to standard coal of 5094 tons, the annual total $\mathrm{CO}_{2}$ emission reduction is 13346 tons ${ }^{[8]}$. 


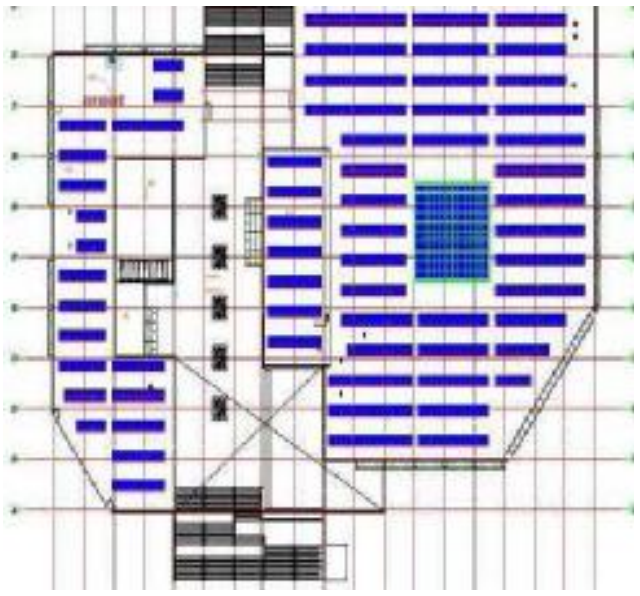

Fig.3 The solar PV square on the floor of the Second Building

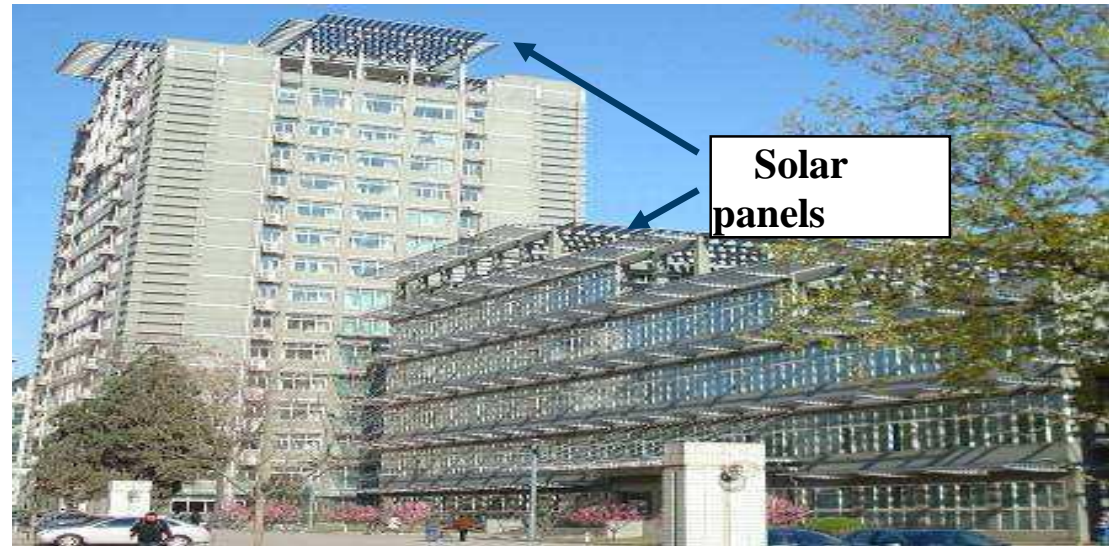

Fig.4 Solar panels on the roof steel frame and the horizontal shading frameForth Building

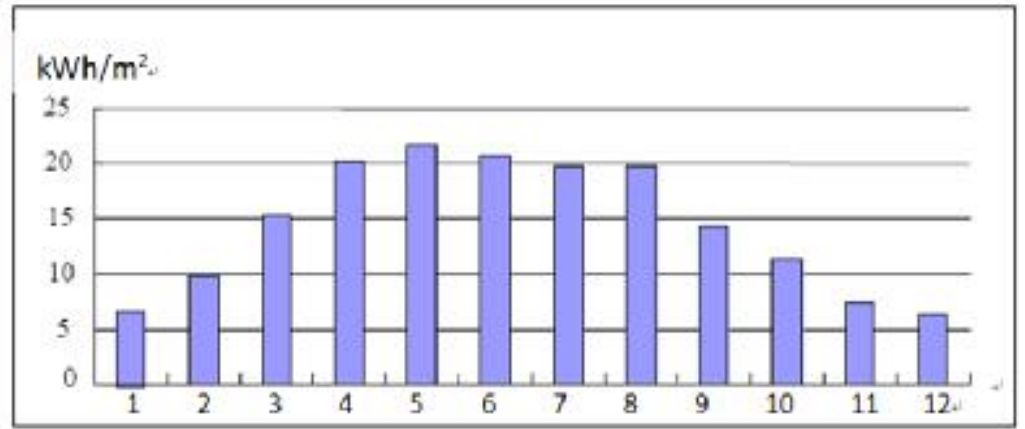

Fig.5 The average monthly electricity generation per square meter

\section{Solar thermal technology}

Solar collectors were installed on the roof of the Eleventh Student Apartment (as shown in figure 6) for the preparation of bath hot water.The total mount of heat collectors is 431 sets, with a total area of $646 \mathrm{~m}^{2}$. Thermal storage tank volume is $40 \mathrm{~m}^{3}$, provide the students of the apartment for bath water all day. Taking the daily average amount of solar radiation $17 \mathrm{MJ} / \mathrm{m}^{2}{ }^{[8]}$ and the efficiency of the collector $50 \%, 300$ days in a year, then the annual average heatcollecting capacity is $1647 \mathrm{GJ}$, equivalent to $157 \mathrm{t}$ of standard coal. Figure 7 is the schematic diagram of the solar hot water system. 


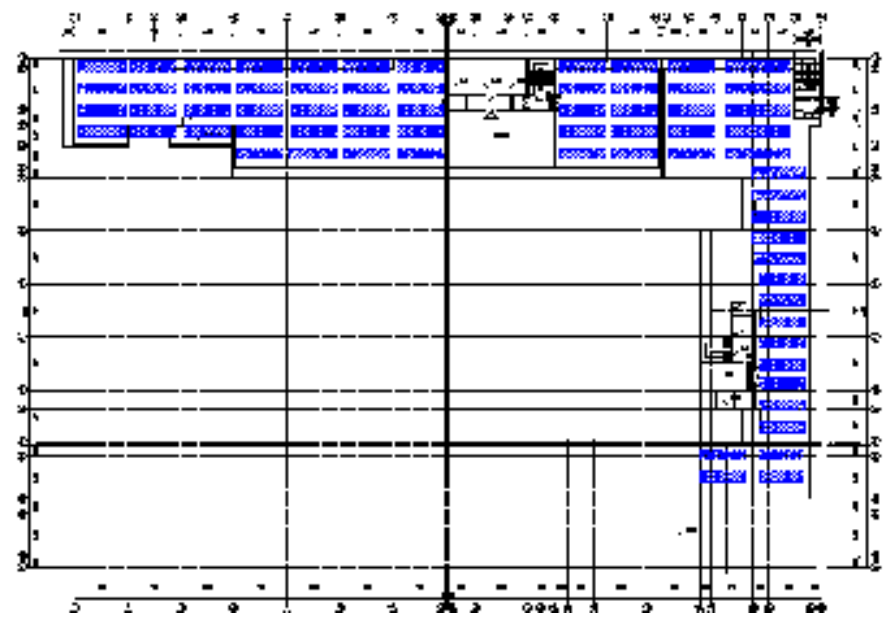

Fig. 6 the solar collectors on the roof of the eleventh apartment

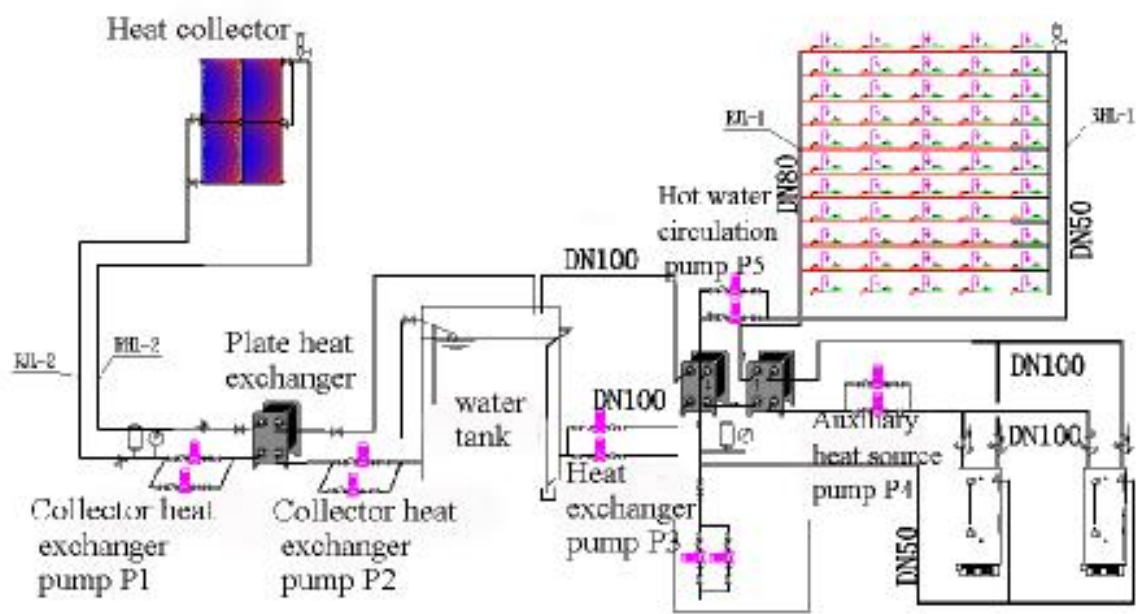

Fig.7 the schematic diagram of the solar hot water system

\section{Energy recovery technology}

\section{Exhaust air heat recovery of air conditioning system}

For large-scale public buildings, such as libraries, teaching buildings, heating and air conditioning load is high, HVAC design scheme usually adopts the centralized all air system or the primary air fancoil system. According to the DesignStandard of Energy Efficiency of Public Buildings, when the fresh air volume is greater than $20000 \mathrm{~m}^{3} / \mathrm{h}$, the central air exhausting system and the heat recovery device should be installed. The school library, teaching building fresh air systems are equipped with fresh air units with recovery device, or equipped with fresh air ventilators. The total volume of the fresh air of air conditioning units and air of the fresh air units is $100000 \mathrm{~m}^{3} / \mathrm{h}$. Using the heat recovery device can save about $20 \%$ of the total energy consumption. Taking air conditioning time as 90 days in winter and 120 days in summer and the efficiency of the heat recovery device as $70 \%$, the average annual heat recovery is $2944 \mathrm{GJ}$, equivalent to 81.7 million KWh electricity.

\section{Recovery of air condition condensation heat}

Taking the school gymnasium for example, the construction area is $13800 \mathrm{~m}^{2}$, with an underground swimming pool, the first floor and the second floor are the badminton hall, the tennis hall and the office accessory room respectively.

\section{1) Analysis load characteristics}

For gymnasiums, especially a comprehensive gymnasium with a swimming pool, cold and heat load is in coexistence in summer. The load of the building is shown in Table $3^{[9]}$. 
Table 3 Energy consumption of stadiums in different seasons $(\mathrm{kW})$

\begin{tabular}{llll}
\hline Seasons & Winter & Summer & transition season \\
\hline pool water heating & 350 & 305 & 324 \\
Bath hot water heating & 312 & 290 & 307 \\
Floor heating in the pool area & 80 & - & - \\
Air cooling(heating)in the pool area & 400 & 319 & - \\
Other rooms cooling & - & 420 & - \\
Other rooms heating & 550 & - & - \\
Total heating load & 1692 & 595 & 631 \\
Total cooling load & 0 & 739 & 0 \\
\hline
\end{tabular}

\section{2) Program selection and energy-saving features}

Combined with the load characteristics of the stadium, the water source heat pump was designed with energy tower, as shown in figure8. Energy saving is reflected in the following aspects: firstly, the condensation heat of air-conditioning system was used in heating pool water and bath water; secondly, the energy tower was used for auxiliary heating, in the transitional season using heat pump and energy tower heating pool water and bath water, the performance coefficient of the heat pump is high, the energy saving effect is remarkable. Thirdly, preparing bath water by heat pump during off-peak period (night) is a good way to save operating costs.

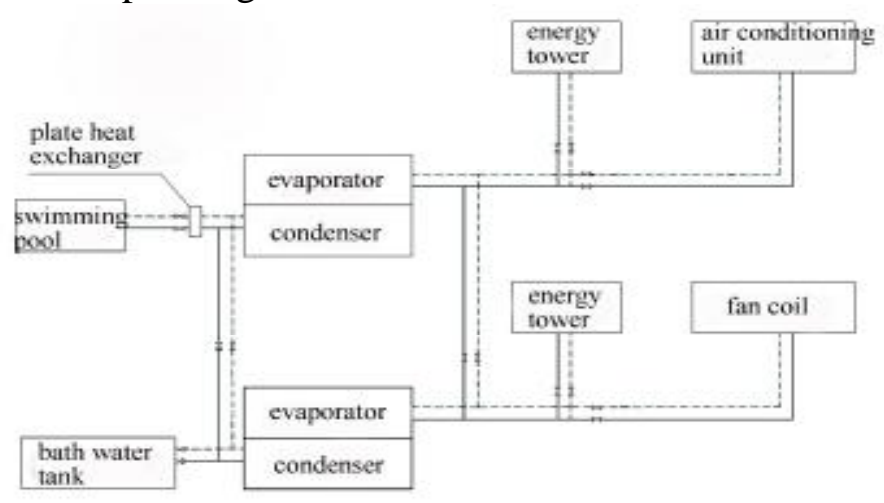

Fig. 8 Cooling and heating principle diagram of the heat pump with energy tower

3) Analysis of energy saving effect

Calculation shows that compared with the traditional water chiller air conditioning system and gas-fired water heating system, the new program can save standard coal $241 \mathrm{t}$ per year, equivalent to $689,900 \mathrm{kWh}$.

Table4 Summary of energy saving and emission reduction

\begin{tabular}{ccccc}
\hline $\begin{array}{c}\text { building energy } \\
\text { saving technology }\end{array}$ & $\begin{array}{c}\text { Annual energy } \\
\text { saving equivalent to } \\
\text { standard coal }(\mathrm{t})\end{array}$ & $\begin{array}{c}\text { Annual electricity } \\
\text { saving } \\
(1000 \mathrm{KWh})\end{array}$ & $\begin{array}{c}\text { Annual emission } \\
\text { reduction of } \mathrm{CO}_{2} \\
(\mathrm{t})\end{array}$ & $\begin{array}{c}\text { Electricity } \\
\text { Saving ratio } \\
\%\end{array}$ \\
\hline $\begin{array}{c}\text { Prepare bath water } \\
\text { by heat pump }\end{array}$ & 245 & 70 & 639 & 3.95 \\
$\begin{array}{c}\text { Photovoltaic lighting } \\
\text { Energy tower and } \\
\text { condensation heat } \\
\text { recovery }\end{array}$ & 197 & 56.6 & 514 & 3.19 \\
$\begin{array}{c}\text { Solar energy heating } \\
\text { bath water }\end{array}$ & 241 & 68.99 & 628 & 3.89 \\
$\begin{array}{c}\text { Exhaust heat } \\
\text { recovery }\end{array}$ & 157 & 44.9 & 409 & 2.53 \\
$\quad$ Total & 285 & 81.7 & 742 & 4.61 \\
\hline
\end{tabular}




\section{Summary of energy saving effect}

Table4 shows the summary of the energy saving effect after using building energy saving technology. The annual electricity consumption statistics can be seen in figure 9 , the total electricity consumption is 17.71 million KWh. The saving energy is $18 \%$ of the total electricity consumption and the annual $\mathrm{CO}_{2}$ emission reduction is $2932 \mathrm{t}$.

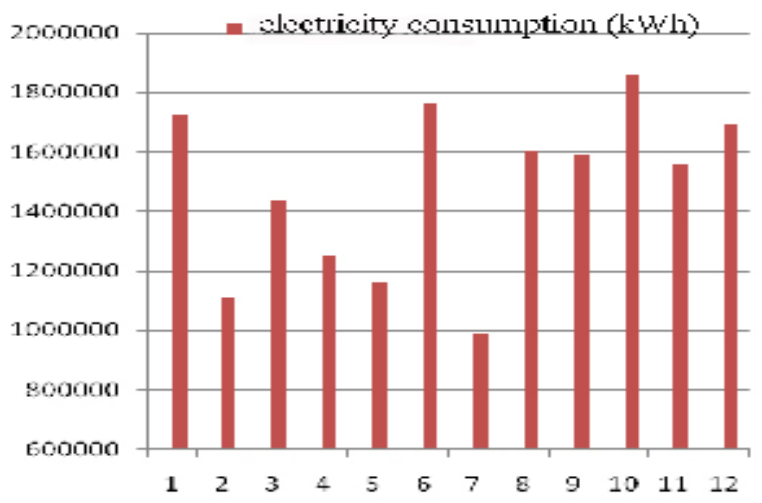

Fig. 9 Statistics of the monthly total electricity consumption of the school

\section{Conclusions}

In this study, several feasible energy saving techniques were developed in HAVC design in NCUT, and the effects of each energy saving technique were investigated. The result showed that the ratio of energy saving accounted for $18 \%$ of the total electricity consumption in the campus, and the greenhouse gas emission reduction was $2932 \mathrm{t}$ every year. This study confirmed that energy-saving HVAC design offer a strategy for reducing the energy use as well as the operating cost in campus.

In order to achieve energy conservation and emissions reduction, renewable energy such as solar photovoltaic, solar thermal technology, energy recovery technology could be used in buildings which have the corresponding operating conditions. College students would have the opportunity to learn and understand the energy saving technology,that will be helpful to enhance the the students' awareness of energy conservation, which has siginificant effect on promoting the construction of a conservation oriented campus.

\section{Reference:}

[1] Tan Hongwei, $\mathrm{Xu}$ Yulin, Hu Chengyi. Response of global climate change and energy conservation regulation of campus building in China [J]. Building Energy \& Environment. 2010,29(1):36-40.

[2] Xuan Zhoua, Junwei Yana,, Junwen Zhuc, Panpan Caia, Survey of energy consumption and energy conservation measures for colleges and universities in Guangdong province, Energy and Buildings[J],Volume 66, November 2013, Pages 112-118

[3]Ying Han, Xuejie Zhou, Ruijiang Luo, Analysis on Campus Energy Consumption and Energy Saving Measures in Cold Region of China, Procedia Engineering[J], Volume 121, 2015, Pages 801-808, ISSN 1877-7058,

[4] Zhuang Zhaoyi, Shang Xianbo, Zhang Chenghu. Technical and economic analysis of direct heat pump system with sewage effluent as heat source [J]. China Water \& Wastewater. 2011, 27(2):24-29.

[5] Shen Chuantao,Peng Donggen,Hu Song. Feasibility analysis of sewage source heat pump system engineering example and application in Nanchang [J]. Renewable energy. 2014,32(2):1510-1514.

[6] Zhou Zhiping, Li Nianping. Application analysis of sewage source heat pump of a large public building [J]. Building technology. 2013,44(4):362-364

[7] Liu Shuang. Utilization of solar energy resources and development of solar energy building [J]. Scientific and technological achievements. 2007,(6):39-40 
[8] Chunxia Jia,Technical and Economic Analysis of BIPV Project in a University Campus of Beijing[C],Advanced Materials Research Vols.450-451 (2012) pp 1477-1481

[9] Lv Bing. Energy saving design of gymnasium with swimming pool [J]. Energy conservation. 2013.(1):22-25 